MAKING CHRISTIANS 



\section{MAKING CHRISTIANS:}

CLEMENT OF ALEXANDRIA AND THE

RHETORIC OF LEGITIMACY

DENISE KIMBER BUELL

PRINCETON UNIVERSITY PRESS

PRINCETON, NEW JERSEY 
Copyright $(\mathcal{O} 1999$ by Princeton University Press

Published by Princeton University Press, 41 William Street,

Princeton, New Jersey 08540

In the United Kingdom: Princeton University Press, Chichester, West Sussex

All Rights Reserved

\section{Library of Comgress Cataloging-in-Publication Data}

Buell, Denise Kimber, 1965-

Making Christians : Clement of Alexandria and the rhetoric of

legitimacy / Denise Kimber Buell.

p. $\mathrm{cm}$.

Includes bibliographical references and index.

ISBN 0-691-05980-2 (alk. paper)

1. Clement, of Alexandria, Saint, ca. 150-ca. 215.

2. Apologetics-History-Early church, ca. 30-600. 3. Human

reproduction-Religious aspects-Christianity-History of doctrines-

Early church, ca. 30-600. 4. Kinship-Religious aspects-

Christianity-History of doctrines-Early church, ca. 30-600.

I. Title.

BR65.C66B84 $1999 \quad 270.1-\mathrm{dc} 21 \quad 98-34873$

This book has been composed in Galliard

The paper used in this publication meets the minimum requirements of ANSI/NISO

Z39.48-1992 (R1997) (Permanence of Paper)

http://pupress.princeton.edu

Printed in the United States of America

$\begin{array}{llllllllll}10 & 9 & 8 & 7 & 6 & 5 & 4 & 3 & 2 & 1\end{array}$ 
To my grandparents 
